\title{
Evidence of inorganic chlorine gases other than hydrogen chloride in marine surface air
}

\section{Citation}

Pszenny, A. A. P., W. C. Keene, D. J. Jacob, S. Fan, J. R. Maben, M. P. Zetwo, M. Springer-Young, and J. N. Galloway. 1993. "Evidence of Inorganic Chlorine Gases Other Than Hydrogen Chloride in Marine Surface Air." Geophys. Res. Lett. 20 (8) (April 23): 699-702. doi:10.1029/93gl00047.

\section{Published Version}

doi:10.1029/93GL00047

\section{Permanent link}

http://nrs.harvard.edu/urn-3:HUL.InstRepos:14121873

\section{Terms of Use}

This article was downloaded from Harvard University's DASH repository, and is made available under the terms and conditions applicable to Other Posted Material, as set forth at http:// nrs.harvard.edu/urn-3:HUL.InstRepos:dash.current.terms-of-use\#LAA

\section{Share Your Story}

The Harvard community has made this article openly available.

Please share how this access benefits you. Submit a story.

\section{Accessibility}




\title{
EVIDENCE OF INORGANIC CHLORINE GASES OTHER THAN HYDROGEN CHLORIDE IN MARINE SURFACE AIR
}

\author{
A. A. P. Pszenny ${ }^{1,4}$, W. C. Keene ${ }^{2}$, D. J. Jacob ${ }^{3}$, S. Fan ${ }^{3}$, J. R. Maben ${ }^{2}$, \\ M. P. Zetwo ${ }^{1}$, M. Springer-Young ${ }^{1}$, and J. N. Galloway ${ }^{2}$
}

Abstract. We report the first measurements of inorganic chlorine gases in the marine atmosphere using a new tandem mist chamber method. Surface air was sampled during four days including one diel cycle in January, 1992, at Virginia Key, Florida. Concentrations of $\mathrm{HCl}^{*}$ (including $\mathrm{HCl}, \mathrm{ClNO}_{3}, \mathrm{ClNO}_{2}$, and $\mathrm{NOCl}$ ) were in the range 40 to $268 \mathrm{pptv}$ and concentrations of $\mathrm{Cl}_{2}{ }^{*}$ (including $\mathrm{Cl}_{2}$ and any $\mathrm{HOCl}$ not trapped in the acidic mist chamber) were in the range $<26$ to $254 \mathrm{pptv} \mathrm{Cl}$. Concentrations of $\mathrm{Cl}_{2}{ }^{*}$ increased during the night, and decreased after sunrise as $\mathrm{HCl}^{*}$ concentrations increased by similar amounts. The measurements suggest an unknown source of either $\mathrm{HOCl}$ or $\mathrm{Cl}_{2}$ to the marine atmosphere. Photochemical model calculations indicate that photolysis of the observed $\mathrm{Cl}_{2}{ }^{*}$ would yield a chlorine atom $(\mathrm{Cl} \cdot)$ concentration of order $10^{4}-10^{5} \mathrm{~cm}^{-3}$. Oxidation by $\mathrm{Cl}$ - would then represent a significant sink for alkanes and dimethylsulfide (DMS) in the marine boundary layer. The cycling of $\mathrm{Cl}$. could provide either a source or a sink for $\mathrm{O}_{3}$, depending on $\mathrm{NO}_{\mathrm{X}}$ levels.

\section{Introduction}

There has been recurring speculation over the years as to the possible role of atomic chlorine $(\mathrm{Cl} \cdot)$ in the chemistry of the marine boundary layer [Wofsy and McElroy, 1974; Finlayson-Pitts, 1983; Finlayson-Pitts et al., 1989; Keene et al., 1990]. Singh and Kasting [1988] reviewed the available data on sources of $\mathrm{Cl}$ - from (1) oxidation of $\mathrm{HCl}$ and $\mathrm{CH}_{3} \mathrm{Cl}$, (2) photolysis of chlorocarbons, (3) aerosol reactions of $\mathrm{ClNO}_{3}$, and (4) reactions of nitrogen oxides on dry $\mathrm{NaCl}$ aerosol. They concluded that these processes are too slow to have much effect on the chemistry of the marine boundary layer, although recent work [e.g., Ganske et al., 1992] suggests that reactions involving nitrogen oxides may be more important than estimated by Singh and Kasting [1988]. Here we report preliminary results which indicate the presence in marine surface air of significant concentrations of inorganic chlorine gases other than $\mathrm{HCl}$. Our results suggest a much greater source of $\mathrm{Cl}$. than believed previously.

\footnotetext{
${ }^{1}$ Atlantic Oceanographic and Meteorological Laboratory, NOAA

${ }^{2}$ Department of Environmental Sciences, University of Virginia

${ }^{3}$ Division of Applied Sciences and Department of Earth and Planetary Sciences, Harvard University

${ }^{4}$ Now at Center for Global Change Science, Massachusetts Institute of Technology

Copyright 1993 by the American Geophysical Union.
}

Paper number 93GL00047

0094-8534/93/93GL-00047\$03.00

\section{Experimental}

Concentrations of inorganic chlorine gases, $\mathrm{O}_{3}, \mathrm{HNO}_{3}$, $\mathrm{SO}_{2}$, and black carbon, and size-segregated aerosol ionic composition were measured on the grounds of the NOAA Atlantic Oceanographic and Meteorological Laboratory (AOML), Virginia Key, Miami, FL (see Figure 1). The gas phase chlorine concentration measurements were made during fourteen 2-hour intervals from 22 to 28 January, 1992, using a new tandem mist chamber method described in detail by Keene et al. [1993]. Briefly: After passing through an inertial preseparator to remove coarse particles ( $>1 \mu \mathrm{m}$ aerodynamic diameter) and a teflon filter (Zefluor, $2 \mu \mathrm{m}$ pore diameter) to remove fine particles the chlorine gases were sampled by an acidic mist chamber containing $37.5 \mathrm{mM} \mathrm{H}_{2} \mathrm{SO}_{4}+0.042 \mathrm{mM}\left(\mathrm{NH}_{4}\right)_{2} \mathrm{SO}_{4}$ followed by an alkaline mist chamber containing $30.0 \mathrm{mM}$ $\mathrm{NaHCO}_{3}+0.408 \mathrm{mM} \mathrm{NaHSO}_{3}$. Tests with permeation sources indicate that all $\mathrm{HCl}$ and a small fraction $(<10 \%)$ of $\mathrm{Cl}_{2}$ was sampled by the acidic mist. Results are corrected for the apparent influence from $\mathrm{Cl}_{2}$, but $\mathrm{CINO}_{3}$, $\mathrm{ClNO}_{2}$, and $\mathrm{NOCl}$ may also have contributed to produce $\mathrm{Cl}^{-}$in the acidic mist chamber. We, therefore, use $\mathrm{HCl}^{*}$ to denote this chlorine gas. If present, a fraction of $\mathrm{HOCl}$ may have been trapped in the acidic mist chamber. Standard additions to mist chamber solutions indicate, however, that $\mathrm{HOCl}$ does not generate $\mathrm{Cl}^{-}$and is thus not detected by the ion chromatographic analytical technique. The alkaline mist chamber trapped $\mathrm{Cl}_{2}$ quantitatively and is expected to trap any $\mathrm{HOCl}$ remaining in the airstream as well. We use the symbol $\mathrm{Cl}_{2}{ }^{*}$ to denote this chlorine. It does not appear that organic chlorine gases are collected in either mist chamber [Keene et al., 1993].

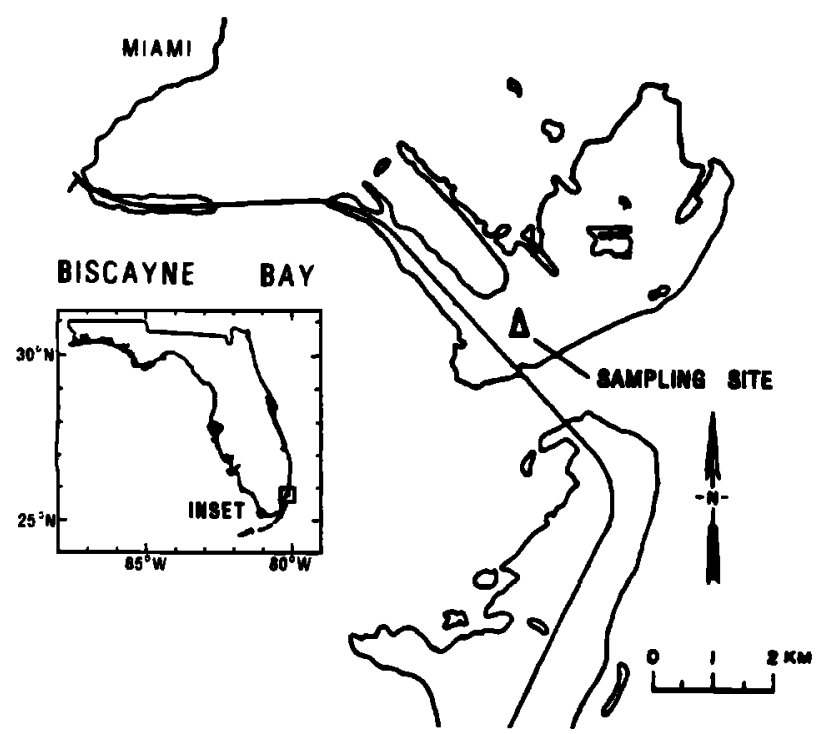

Fig. 1. Location of sampling site on Virginia Key, near Miami, Florida. 
Pszenny et al.: Inorganic Chlorine in Marine Surface Air

Table 1. Meteorological Data and Gas Phase Species Concentrations

\begin{tabular}{|c|c|c|c|c|c|c|c|c|c|c|c|}
\hline Interva! & $\begin{array}{l}\text { Start }^{\dagger} \\
(\text { EST) }\end{array}$ & $\begin{array}{c}\text { End } \\
\text { (EST) }\end{array}$ & $\begin{array}{c}T \\
\left({ }^{\circ} \mathrm{C}\right)\end{array}$ & $\begin{array}{c}\text { R.H. } \\
(\%)\end{array}$ & $\begin{array}{c}\text { Wind } \\
\text { Direction } \\
\text { (degrees) }\end{array}$ & $\begin{array}{c}\text { Wind } \\
\text { Speed } \\
\left(\mathrm{m} \mathrm{s}^{-1}\right)\end{array}$ & $\begin{array}{l}\mathrm{HCl}^{* \ddagger} \\
\text { (pptv) }\end{array}$ & $\begin{array}{c}\mathrm{Cl}_{2}{ }^{* \ddagger} \\
(\mathrm{pptv} \mathrm{Cl})\end{array}$ & $\begin{array}{c}\mathrm{O}_{3}^{*} \\
(\mathrm{ppbv})\end{array}$ & $\begin{array}{c}\mathrm{HNO}_{3}{ }^{*} \\
(\mathrm{pptv})\end{array}$ & $\begin{array}{r}\mathrm{SO}_{2}{ }^{\ddagger} \\
\text { (pptv) }\end{array}$ \\
\hline \multicolumn{12}{|c|}{22 January 1992} \\
\hline 1 & 1514 & 1714 & 21 & 80 & 120 & 7.5 & 192 & $<40$ & 40 & $<25$ & 140 \\
\hline \multicolumn{12}{|c|}{23 January 1992} \\
\hline 2 & 0425 & 0625 & 22 & $>98$ & 170 & 7. & 40 & 26 & 26 & $<25$ & 40 \\
\hline 3 & 0651 & 0851 & 22 & $>98$ & 180 & 8. & 63 & $<26$ & 22 & $<25$ & 100 \\
\hline 4 & 0921 & 1122 & 22 & $>98$ & 180 & 7.5 & 58 & $<26$ & 19 & $<25$ & 80 \\
\hline \multicolumn{12}{|c|}{ 27-28 January 1992} \\
\hline 5 & 1504 & 1704 & 21 & 85 & 115 & 9.5 & 199 & 38 & 37 & $<30$ & 75 \\
\hline 6 & 1729 & 1929 & 21 & 92 & 130 & 9. & 150 & 50 & 37 & $<30$ & 100 \\
\hline 7 & 2000 & 2200 & 21 & 93 & 135 & 8.5 & 152 & 74 & 36 & $<30$ & 98 \\
\hline 8 & 2219 & 0019 & 21 & 94 & 140 & 8. & 146 & 80 & 36 & $<30$ & 76 \\
\hline 9 & 0045 & 0245 & 21 & 94 & 140 & 8. & 152 & 206 & 36 & $<30$ & 99 \\
\hline 10 & 0308 & 0508 & 21 & 98 & 140 & 7. & 151 & 196 & 36 & 39 & 150 \\
\hline 11 & 0530 & 0731 & 21 & 99 & 150 & 6. & 144 & 254 & 34 & $<30$ & 130 \\
\hline 12 & 0741 & 0941 & 22 & 97 & 150 & 6. & 187 & 220 & 33 & $<32$ & 76 \\
\hline 13 & 0954 & 1155 & 23 & 91 & 155 & 6. & 239 & 152 & 31 & $<30$ & 64 \\
\hline 14 & 1205 & 1405 & 24 & 90 & 160 & 5.5 & 268 & 168 & 29 & 15 & 150 \\
\hline
\end{tabular}

${ }^{\dagger} \mathrm{EST}=$ Eastern Standard Time $=$ UTC -5 hours.

${ }^{\ddagger}$ Standard errors: $\mathrm{HCl}^{*} \pm 20 \mathrm{pptv} ; \mathrm{Cl}_{2}^{*} \pm 13 \mathrm{pptv} \mathrm{Cl} ; \mathrm{O}_{3} \pm 1 \mathrm{ppbv} ; \mathrm{HNO}_{3} \pm 13 \mathrm{pptv} ; \mathrm{SO}_{2} \pm 20 \mathrm{pptv}$.

Filter packs were used to collect $\mathrm{HNO}_{3}$ and $\mathrm{SO}_{2}$ over 2-hour intervals and cascade impactors were used to collect size-segregated aerosols over 2- or 4-hour intervals following procedures described by Keene et al. [1990]. Concentrations of $\mathrm{O}_{3}$ were determined by UV photometry [Piotrowicz et al., 1990]. Black carbon concentrations were measured every 5 minutes with an aethalometer [Hansen et al., 1990]. All sampler intakes were mounted on a $10-\mathrm{m}$ scaffolding tower. Vacuum lines connected samplers to air pumps located in a van at the base of the tower.
Meteorological data were recorded with instruments located on the roof of the AOML building. Skies were generally clear with scattered low-level cumulus clouds. Thicker cloud cover and light, widely scattered showers were observed during sampling intervals $3,4,5$, and 14 (Table 1).

\section{Results and Discussion}

The chemical data are given in Tables 1 and 2. A few measurements on 22-23 January indicate $\mathrm{Cl}_{2}{ }^{*}$ concentra-

Table 2. Aerosol Species Concentrations

\begin{tabular}{|c|c|c|c|c|c|c|}
\hline Interval & $\begin{array}{c}\mathrm{NO}_{3}^{-\dagger} \\
\left(\mathrm{nmol} \mathrm{m}^{-3}\right)\end{array}$ & $\begin{array}{c}\mathrm{nss}-\mathrm{SO}_{4}{ }^{+\dagger} \\
\left(\mathrm{nmol} \mathrm{m}{ }^{-3}\right)\end{array}$ & $\begin{array}{c}\mathrm{NH}_{4}^{+\dagger} \\
\left(\mathrm{nmol} \mathrm{m}{ }^{-3}\right) \\
\end{array}$ & $\begin{array}{c}\text { Black Carbon } \\
\left(\mathrm{ng} \mathrm{m}^{-3}\right)\end{array}$ & $\begin{array}{l}\text { Coarse } \mathrm{Cl}^{-7} \\
\left(\mathrm{nmol} \mathrm{m} \mathrm{m}^{-3}\right) \\
\end{array}$ & $\begin{array}{c}\text { Coarse nss-Cl- } \\
\left(\mathrm{nmol} \mathrm{m}^{-3}\right) \\
\end{array}$ \\
\hline \multicolumn{7}{|c|}{ 22. January 1992} \\
\hline 1 & $15 \pm 1$ & $5 \pm 1$ & $6 \pm 2$ & 55 & $210 \pm 3$ & $14 \pm 13$ \\
\hline \multicolumn{7}{|c|}{23 January 1992} \\
\hline $2+3$ & $7 \pm 1$ & $6 \pm 1$ & $12 \pm 3$ & 110 & $250 \pm 3$ & $10 \pm 3$ \\
\hline 4 & $6 \pm 1$ & $7 \pm 1$ & $4 \pm 2$ & 190 & $240 \pm 3$ & $-1.6 \pm 16$ \\
\hline \multicolumn{7}{|c|}{ 27-28 January 1992} \\
\hline $5+6$ & $18 \pm 1$ & $18 \pm 1$ & $15 \pm 3$ & 92 & $280 \pm 3$ & $1.7 \pm 17$ \\
\hline $7+8$ & $15 \pm 1$ & $18 \pm 1$ & $16 \pm 3$ & 89 & $320 \pm 4$ & $0.9 \pm 20$ \\
\hline $9+10$ & $15 \pm 1$ & No data & $14 \pm 3$ & 68 & $220 \pm 4$ & $-14 \pm 22$ \\
\hline $11+12$ & $12 \pm 1$ & $17 \pm 1$ & $14 \pm 3$ & 75 & $260 \pm 3$ & $1.4 \pm 16$ \\
\hline $13+14$ & $15 \pm 1$ & $16 \pm 1$ & $17 \pm 3$ & 120 & $230 \pm 3$ & $3.3 \pm 14$ \\
\hline$\overline{\text { Virginia Key, FI }}$ & ----- & ---- & ----- & ----- & ----- & ------ \\
\hline \multicolumn{7}{|c|}{ Virginia Key, FL (Ref. 1) } \\
\hline $\begin{array}{l}\text { Jan-Mar } 1984 \\
\text { Jul-Sept } 1984\end{array}$ & 45 & 35 & -- & -- & & \\
\hline & 31 & 22 & - & - & & \\
\hline \multicolumn{7}{|c|}{ Subtropical North Allantic background (Refs. 2 and 3) } \\
\hline 1988 & & & & & & \\
\hline
\end{tabular}




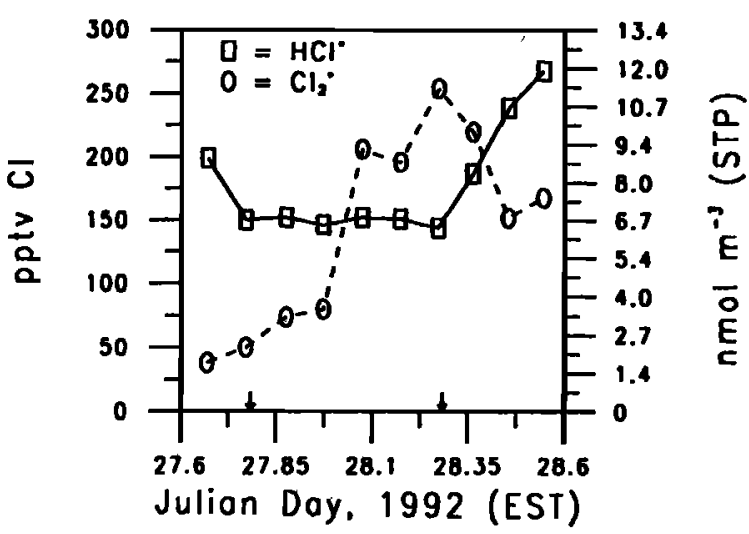

Fig. 2. Diel cycles of $\mathrm{HCl}^{*}$ and $\mathrm{Cl}_{2}{ }^{*}$ concentrations in surface air at Virginia Key, 27-28 January, 1992. Data for both species are in units of pptv $\mathrm{Cl}$, and are plotted at midpoints of 2-hour sampling intervals. Sunset and sunrise (marked with arrows) were at 1802 and 0706 EST, respectively.

tions at or below the detection limit. However, measurements over a full diel cycle on 27-28 January indicate substantial concentrations. The $\mathrm{HCl}^{*}$ and $\mathrm{Cl}_{2}{ }^{*}$ data for 27-28 January are plotted in Figure 2. During this diel cycle concentrations of $\mathrm{HCl}^{*}$ ranged from 144 to $268 \mathrm{pptv} \mathrm{Cl}$ with a daytime maximum. Concentrations of $\mathrm{Cl}_{2}{ }^{*}$ ranged from 38 to 254 pptv $\mathrm{Cl}$ with a nighttime maximum. The $\mathrm{Cl}_{2}{ }^{*}$ peak just before dawn is consistent with a photolysis sink. The opposite trends in $\mathrm{HCl}^{*}$ and $\mathrm{Cl}_{2}{ }^{*}$ during the morning hours suggest that $\mathrm{HCl}^{*}$ was produced following the photolysis of $\mathrm{Cl}_{2}{ }^{*}$.

The chemical data for sea-salt-sized aerosols (Table 2) indicate no significant $\mathrm{Cl}^{-}$deficit like Keene et al. [1990] observed over the open North Atlantic. However, the sums of the observed $\mathrm{HCl}^{*}$ and $\mathrm{Cl}_{2}{ }^{*}$ concentrations are smaller than the uncertainties in nss- $\mathrm{Cl}^{-}$concentrations, so our data are not inconsistent with a sea-salt origin for the gaseous chlorine.

Local winds during our sampling indicated a predominantly marine fetch (see Table 1 and Figure 1). The observed concentrations of $\mathrm{HNO}_{3}, \mathrm{SO}_{2}$ (Table 1) and total aerosol $\mathrm{NO}_{3}^{-}$, non-sea-salt (nss) $\mathrm{SO}_{4}{ }^{-}, \mathrm{NH}_{4}{ }^{+}$, and black carbon (Table 2) suggest that the air sampled was relatively unpolluted for the locale, but certainly polluted compared to subtropical North Atlantic background. Direct anthropogenic sources for $\mathrm{Cl}_{2}{ }^{*}$ probably were unimportant, however, given the short lifetimes of $\mathrm{Cl}_{2}$ and $\mathrm{HOCl}$ against photolysis, and the lower concentrations of $\mathrm{HCl}^{*}$ and $\mathrm{Cl}_{2}{ }^{*}$ observed on 23 January when Key Biscayne was directly upwind. A chemical source in the atmosphere appears to be needed to explain our observed $\mathrm{Cl}_{2}{ }^{*}$ concentrations.

We examine the potential implications of the measured $\mathrm{Cl}_{2}{ }^{*}$ concentrations using the photochemical box model described by Keene et al. [1990]. The model is applied to a marine surface air parcel containing $200 \mathrm{pptv} \mathrm{HCl}$, 35 ppbv $\mathrm{O}_{3}, 22 \mathrm{hPa} \mathrm{H}_{2} \mathrm{O}, 100$ pptv $\mathrm{NO}_{\mathrm{X}}\left(\mathrm{NO}+\mathrm{NO}_{2}\right)$, 150 ppbv $\mathrm{CO}, 1800$ ppbv $\mathrm{CH}_{4}, 2$ ppbv $\mathrm{C}_{2} \mathrm{H}_{6}, 500$ pptv $\mathrm{C}_{3} \mathrm{H}_{8}$, and 50 pptv DMS, representing relatively clean conditions at northern mid-latitudes in winter. Concentrations of radicals and other secondary species are calculated assuming chemical steady-state. Photolysis rate constants are calculated with a 6-stream radiative transfer model for the Rayleigh scattering atmosphere, assuming clear sky conditions at noon and an $\mathrm{O}_{3}$ column of 270 Dobson units.

Model results are shown in Table 3 . In simulation A we compute the steady-state concentrations of gas-phase chlorine species other than $\mathrm{HCl}$ by using a standard gasphase chemistry mechanism with $\mathrm{HCl}+-\mathrm{OH}$ as the primary Cl- source [Singh and Kasting, 1988]. This simulation yields $0.6 \mathrm{pptv} \mathrm{HOCl}$ and no $\mathrm{Cl}_{2}$, inconsistent with observed $\mathrm{Cl}_{2}{ }^{*}$ levels and suggesting the need for an additional source of $\mathrm{Cl}_{2}{ }^{*}$. In simulation $\mathrm{B}$ we assume a missing source of $\mathrm{Cl}_{2}$ constrained to yield a steady-state $\mathrm{Cl}_{2}$ concentration of $100 \mathrm{pptv} \mathrm{Cl}$, representative of observations for $\mathrm{Cl}_{2}{ }^{*}$ on 27-28 January. However, this simulation yields a steady-state $\mathrm{HOCl}$ concentration of $134 \mathrm{pptv}$ from the $\mathrm{ClO} \cdot+\mathrm{HO}_{2} \cdot$ reaction; thus it would overpredict $\mathrm{Cl}_{2} *$ if $\mathrm{HOCl}$ were sampled as $\mathrm{Cl}_{2}{ }^{*}$. In simulation $\mathrm{C}$ we assume a more modest source of $\mathrm{Cl}_{2}$ constrained to yield a $\mathrm{Cl}_{2}$ concentration of $50 \mathrm{pptv} \mathrm{Cl}$; the resulting steady-state concentration of $\mathrm{HOCl}$ is $67 \mathrm{pptv}$, and the sum $\left(\mathrm{Cl}_{2}+\mathrm{HOCl}\right)$ is 117 pptv $\mathrm{Cl}$. Finally, in simulation $\mathrm{D}$ we examine the possibility that the observed $\mathrm{Cl}_{2}{ }^{*}$ may be supplied by a missing source of $\mathrm{HOCl}$ constrained to yield a steady-state $\mathrm{HOCl}$ concentration of $100 \mathrm{pptv}$. There is no significant $\mathrm{Cl}_{2}$ production in this last simulation.

Results indicate noontime concentrations of $\mathrm{Cl} \cdot$ in the range $0.3-1 \times 10^{5} \mathrm{~cm}^{-3}$ for simulations $\mathrm{C}$ and $\mathrm{D}$. The $\mathrm{Cl}$.

Table 3. Results of Photochemical Model Simulations

\begin{tabular}{lcccc}
\hline Simulation $^{\dagger}$ & A & B & C & D \\
\hline 1. Speciation of chlorine (pptv Cl) & & \\
$\mathrm{Cl}_{2}$ & 0. & 100. & 50. & 0. \\
$\mathrm{HOCl}$ & 0.6 & 134. & 67. & 100. \\
$\mathrm{HCl}$ & 200. & 200. & 200. & 200. \\
$\mathrm{ClNO}_{3}$ & 0.4 & 97. & 48. & 8.6
\end{tabular}

2. Required $\mathrm{Cl}_{2}{ }^{*}$ source (pptv $\mathrm{Cl} \mathrm{h}^{-1}$ )
0 .
570.
290.
50.

3. Oxidant concentrations (molecules $\mathrm{cm}^{-3}$ )

$\begin{array}{lllll}\mathrm{Cl} \cdot & 1.4 \mathrm{E} 3 \mp & 2.6 \mathrm{E} 5 & 1.4 \mathrm{E} 5 & 2.8 \mathrm{E} 4 \\ . \mathrm{OH} & 4.4 \mathrm{E} 6 & 3.6 \mathrm{E} 6 & 3.9 \mathrm{E} 6 & 4.5 \mathrm{E} 6\end{array}$

4. Fraction of loss due to oxidation by $\mathrm{Cl}$.

\begin{tabular}{lllll}
$\mathrm{CH}_{4}$ & 0.005 & 0.53 & 0.36 & 0.087 \\
$\mathrm{C}_{2} \mathrm{H}_{6}$ & 0.073 & 0.95 & 0.90 & 0.61 \\
$\mathrm{C}_{3} \mathrm{H}_{8}$ & 0.036 & 0.90 & 0.82 & 0.43 \\
$\mathrm{DMS}$ & 0.003 & 0.44 & 0.28 & 0.063 \\
\hline
\end{tabular}

†All simulations are for a marine surface air parcel at noon. Simulation $\mathrm{A}$ includes $\mathrm{HCl}+\cdot \cdot \mathrm{OH}$ as the primary $\mathrm{Cl}$ - source; simulation $\mathrm{B}$ assumes a missing source of $\mathrm{Cl}_{2}$ constrained to yield a $\mathrm{Cl}_{2}$ concentration of $100 \mathrm{pptv} \mathrm{Cl}$; simulation $\mathrm{C}$ assumes a missing source of $\mathrm{Cl}_{2}$ constrained to yield a $\mathrm{Cl}_{2}$ concentration of $50 \mathrm{pptv} \mathrm{Cl}$; simulation $\mathrm{D}$ assumes a missing source of $\mathrm{HOCl}$ constrained to yield a $\mathrm{HOCl}$ concentration of 100 pptv $\mathrm{Cl}$.

$¥ 1.4 \mathrm{E} 3=1.4 \times 10^{3}$, etc. 
concentration is higher in simulation $\mathrm{C}$ because the photolysis rate constant of $\mathrm{Cl}_{2}$ at noon $\left(\mathrm{k}=1.6 \times 10^{-3} \mathrm{~s}^{-1}\right)$ is greater than that of $\mathrm{HOCl}\left(\mathrm{k}=1.5 \times 10^{-4} \mathrm{~s}^{-1}\right)$. Oxidation by $\mathrm{Cl} \cdot$ in simulations $\mathrm{C}$ and $\mathrm{D}$ accounts for significant fractions of the total chemical losses of $\mathrm{CH}_{4}, \mathrm{C}_{2} \mathrm{H}_{6}, \mathrm{C}_{3} \mathrm{H}_{8}$, and DMS.

Chlorine chemistry also modifies the $\mathrm{O}_{3}$ budget in two principal ways. Rapid $\mathrm{O}_{3}$ loss takes place by the reaction sequence:

$$
\begin{aligned}
& \mathrm{Cl} \bullet+\mathrm{O}_{3} \rightarrow \mathrm{ClO} \cdot+\mathrm{O}_{2} \\
& \mathrm{ClO} \cdot+\mathrm{HO}_{2} \cdot \mathrm{HOCl}+\mathrm{O}_{2} \\
& \mathrm{HOCl}+\mathrm{h \nu} \rightarrow \cdot \mathrm{OH}+\mathrm{Cl} \bullet
\end{aligned}
$$

However, this loss can be compensated by enhanced supply of odd hydrogen radicals from the oxidation of alkanes by $\mathrm{Cl} \cdot$, leading to $\mathrm{O}_{3}$ production in the presence of sufficient $\mathrm{NO}_{\mathrm{X}}$. The net effect of chlorine chemistry is thus to increase $\mathrm{O}_{3}$ loss at $\mathrm{NO}_{\mathrm{X}}$ concentrations below about 20 pptv and to stimulate $\mathrm{O}_{3}$ production at higher $\mathrm{NO}_{X}$ concentrations.

Simulation $\mathrm{C}$ requires a $\mathrm{Cl}_{2}$ source of 300 pptv $\mathrm{h}^{-1}$, while simulation $\mathrm{D}$ requires an $\mathrm{HOCl}$ source of $50 \mathrm{pptv} \mathrm{h}^{-1}$. The sources are uncertain, but our data offer a few clues. First, the steady rise of $\mathrm{Cl}_{2}{ }^{*}$ following sunset may indicate a non-photochemical source. Second, the rate of decline of $\mathrm{Cl}_{2}{ }^{*}$ following sunrise suggests a lifetime against photolysis on the order of a few hours, implying that $\mathrm{HOCl}$ rather than $\mathrm{Cl}_{2}$ dominates the $\mathrm{Cl}_{2}{ }^{*}$ pool. at least at night. Improved understanding of chlorine chemistry in the marine boundary layer is evidently needed in view of its potential importance for global atmospheric chemistry.

Acknowledgements. N. Dorst, AOML Hurricane Research Division, provided the meteorological data. A. Mendez (AOML) assisted with sampling and aerosol sample analysis. We thank $H$. Cruden and W. Shoup (U. Virginia) and R. Calvert, C. Fischer, S. Jones, and M. Shoemaker (AOML) for equipment preparation. R. Joyce of Dionex Corporation provided technical support. This work was supported by NSF Grants ATM-9103742-01 and ATM9013128-02, and NOAA contract 50-EANR-2-0001 to the University of Virginia, NSF Grant ATM-8858074 to Harvard University, NOAA/AOML base funding, and the NOAA Climate and Global Change program.

\section{References}

Finlayson-Pitts, B. J., Reaction of $\mathrm{NO}_{2}$ with $\mathrm{NaCl}$ and atmospheric implications for $\mathrm{NOCl}$ formation, Nature, 306, 676-677, 1983.

Finlayson-Pitts, B. J., M. J. Ezell, and J. N. Pitts, Jr., Formation of chemically active chlorine compounds by reactions of atmospheric $\mathrm{NaCl}$ particles with gaseous $\mathrm{N}_{2} \mathrm{O}_{5}$ and $\mathrm{ClONO}_{2}$, Nature, 337, 241-244, 1989.
Ganske, J. A., H. N. Berko, and B. J. Finlayson-Pitts, Absorption cross sections for gaseous $\mathrm{CINO}_{2}$ and $\mathrm{Cl}_{2}$ at 298K: Potential organic oxidant source in the marine troposphere. J. Geophys. Res., 97, 7651-7656, 1992.

Hansen, A. D. A., R. S. Artz, A. A. P. Pszenny, and R. E. Larson, Aerosol black carbon and radon as tracers for air mass origin over the North Atlantic Ocean, Global Biogeochem. Cycles, 4, 189-199, 1990.

Keene, W. C., A. A. P. Pszenny, D. J. Jacob, R. A. Duce, J. N. Galloway, J. J. Schultz-Tokos, H. Sievering, and J. Boatman, The geochemical cycling of reactive chlorine through the marine troposphere, Global Biogeochem. Cycles, 4, 407-430, 1990.

Keene, W. C., J. R. Maben, A. A. P. Pšzenny, and J. N. Galloway, A measurement technique for inorganic chlorine gases in the marine boundary layer. Environ. Sci. Technol., in press, 1993.

Piotrowicz, S. R., C. J. Fischer, and R. S. Artz, Ozone and carbon monoxide over the North Atlantic during a boreal summer, Global Biogeochem. Cycles, 4, 215-224, 1990.

Pszenny, A. A. P., G. R. Harvey, C. J. Brown, R. F. Lang, W. C. Keene, J. N. Galloway, and J. T. Merrill, Measurements of dimethylsulfide oxidation products in the summertime North Atlantic marine boundary layer, Global Biogeochem. Cycles, 4, 367-379, 1990.

Savoie, D. L., J. M. Prospero, and R. T. Nees, Washout ratios of nitrate, non-sea-salt sulfate, and sea-salt on Virginia Key, Florida, and on American Samoa, Atmos. Environ., 21, 103-112, 1987.

Singh, H. B., and J. F. Kasting, Chlorine-hydrocarbon photochemistry in the marine troposphere and lower stratosphere, J. Atmos. Chem., 7, 261-285, 1988.

Wofsy, S. C., and M. B. McElroy, $\mathrm{HO}_{X}, \mathrm{NO}_{X}$, and $\mathrm{Cl}_{X}$ : Their role in atmospheric photochemistry, Can. J. Chem., 52, 1582-1591, 1974.

J. N. Galloway, W. C. Keene, and J. R. Maben, Department of Environmental Sciences, Clark Hall, University of Virginia, Charlottesville, VA 22903.

S. Fan and D. J. Jacob, Department of Earth and Planetary Sciences, Pierce Hall, Harvard University, 29 Oxford Street, Cambridge, MA 02138.

A. A. P. Pszenny*, M. Springer-Young, and M. P. Zetwo, Ocean Chemistry Division, Atlantic Oceanographic and Meteorological Laboratory, NOAA, 4301 Rickenbacker Causeway, Miami, FL 33149.

*Now at Center for Global Change Science, Bldg. 24-409, Massachusetts Institute of Technology, Cambridge, MA 02139.

(Received October 20, 1992; accepted December 29, 1992.) 